依 頼 論 文
企画 : 第 2 回補綴歯科臨床研鑽会プロソ'16 / シンポジウム 3 「コンプリートデンチャーによる機能回復」

\title{
DENTCA システムおよびピエゾグラフィーを応用した全部床義歯
}

\author{
新保秀仁，仲田豊生，徳江＼cjkstart藍，栗原大介，大久保力廣 \\ Construction of complete dentures using DENTCA system and Piezography technique \\ Hidemasa Shimpo, DMD, PhD, Toyoki Nakata, DMD, PhD, Ai Tokue, DMD, PhD, \\ Daisuke Kurihara, DMD, PhD and Chikahiro Ohkubo, DMD, PhD
}

\begin{abstract}
抄 録
近年, デジタルテクノロジーの発展はめざましく, 可撤性補綴分野にも広く導入されつつある。当講座ではデ ジタルテクノロジーを用いた CAD/CAM デンチャーとしてDENTCA システムを採用している. CAD/CAM デ ンチャーは情報の保存や伝達が容易, 製作期間の短縮, エラーが少ないなど多くの利点を有する。 また, 従来 の全部床義歯製作方法においてもデンチャースペースを採得し，生理的な形態を付与することを重視しており， 特に発音を利用するピエゾグラフィーを積極的に臨床応用している. 今回は, DENTCA システムの臨床術式と DENTCA システムに用いられているCAD を利用した解剖学的構造の抽出およびデンチャースペース情報を義 歯形態に反映させた臨床例を報告する。
\end{abstract}

キーワード

DENTCA システム，ピエゾグラフィー，CAD/CAM デンチャー，デジタルリリーフ

\section{I. 緒言}

補綴治療のクオリティーは材料の品質や歯科医師, 歯科技工士の技術によって補償されてきたが，均質で 高精度な補綴装置を提供し続けることは容易ではな かった。近年，デジタルテクノロジーの発展はめざま しく, 歯科医療への応用も急加速している。 ヒュー マンエラーの軽減, 補綴装置の優れた再現性や安定 性，情報の伝達や保存が容易など多様な利益をもたら すことから, 固定性補綴装置の分野においてはフルデ ジタルプロセスによる補綴装置の製作がすでに日常臨 床で応用されている. 現在, 有床義歯分野においても $\mathrm{CAD} / \mathrm{CAM}$ 技術を応用したデジタルデンチャーの製 作が試みられており, 臨床応用可能なレベルにまで発 展している。しかし, 全ての工程を $\mathrm{CAD} / \mathrm{CAM}$ で製 作するにはいくつかの問題が残されている.そこで, $\mathrm{CAD} / \mathrm{CAM}$ デンチャー製作法として当講座で採用し
ている DENTCA システムの臨床術式とともに, CAD を応用した全部床義歯治療の臨床例を報告する。

\section{DENTCA システム}

DENTCA システム (Nexteeth ${ }^{\mathrm{TM}}$, Whole you Inc., Torrance, USA, DENTCA Inc., Torrance, USA, 三 井化学グループ, 東京, 日本) は2007 年に Kim ら によって考案された, デジタル技術を応用した全部床 義歯製作術式である ${ }^{1)}$. 従来の製作術式ではゴシック アーチ描記を含めると義歯装着まで 6 回の来院が必要 になるが, DENTCA システムは来院回数を大きく減 少できることが特徴である。その術式は(1) DENTCA トレーによる印象採得，ゴシックアーチ描記，咬合採 得, (2) Try-in デンチャーによる試適，(3)全部床義歯 装着といった 3 回の治療ステップによって義歯の装 着が可能である。 DENTCA トレーと呼ばれる専用の 

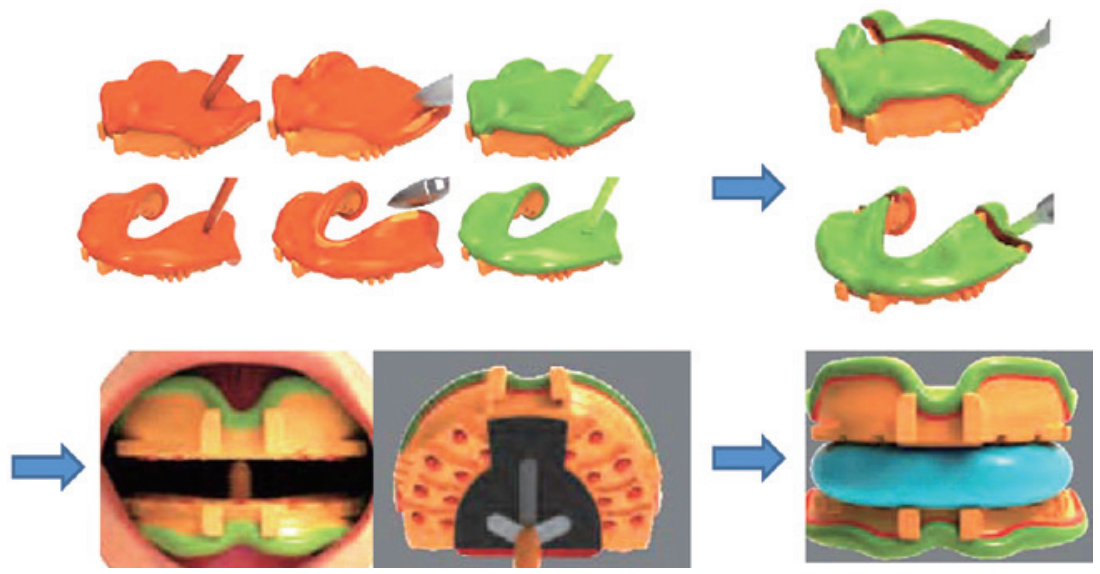

図 1 DENTCA トレーによる印象採得と咬合採得

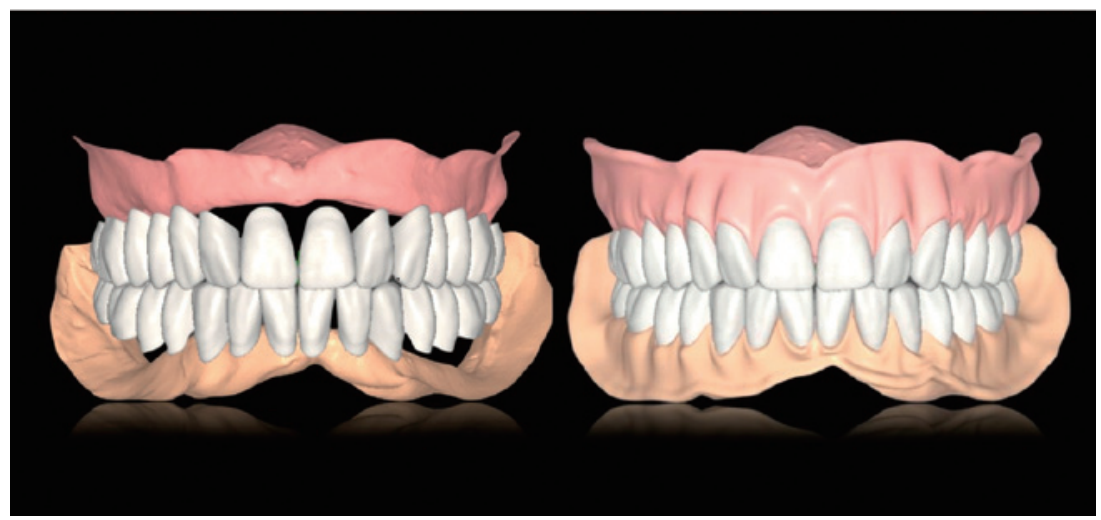

図 2 人工歯排列と義歯床のデザイン

トレーは 4 種類のサイズがあり，顎堤の大きさに応じ て選択する。上顎にはゴシックアーチ描記板があらか じめ付与されており，下顎には描記針を設置できる構 造となっている。上下顎ともにトレー後方部が分割可 能であり，印象体を用いた咬合採得時に顎堤後方部の クリアランスを確保することができる．DENTCA ト レーはプラスティック製の既製品であることから，辺 縁形態が不適合であることも多く, 加温による屈曲や エンジンバーによる削除調整を行う。印象採得はシリ コーン印象材へビーボディタイプにて 1 次印象採得 後, 最終的にレギュラーボディタイプにて 2 次印象 採得を行っている. 印象採得後, 印象体の後方を切断・ 分離し,ゴシックアーチ描記および咬合採得を行う (図 1)。最後に顔貌情報として，上唇の長さを専用のルー ラーを使用して計測する。

印象体をスキャン後，顎堤形態および上下顎の顎 間関係をバーチャル上にて 3 次元構築し，人工歯排 列および義歯床形態のシミュレーションを行う（図 2). CAD 上でのデザインに従って 3D プリンターに
より Try-in デンチャーを製作し（図 3)，口腔内にて 試適を行う。印象採得や顎間関係に問題がある場合 は，Try-in デンチャーを利用して再印象やチェック バイトを採得する。 Try-in デンチャーの形態を基に 高強度 PMMA レジンブロックを使用し，ミリングに よる義歯床の製作および既成人工歯の接着を行い，全 部床義歯を完成する（図 4)。ミリング加工された義 歯床は高い精度と強度を実現しているため, 従来法と 比較して口蓋床を薄く製作することが可能である。ま た，部分床義歯のレジン部や顎義歯など複雑な構造に 対応していくために，3D プリンターによる義歯床お よび人工歯の製作も試みられている ${ }^{2)}$. しかし, 現在 の 3D プリンティング材料はミリング用レジンと比較 すると理工学的性質に劣ることから，長期経過による 破損や摩耗が懸念され, 高強度の 3D プリンター用レ ジンの開発が期待されている.

現在, CAD/CAM によるコンプリートデンチャー の製作方法はいくつか報告されており，DENTCA シ ステムを含めてすでに海外で上市されているシステム 


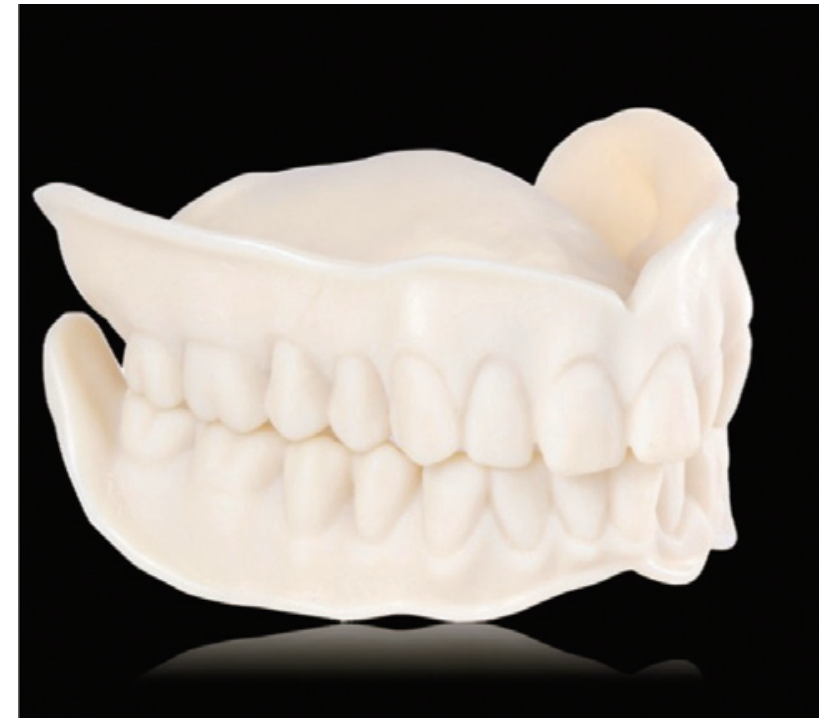

図 3 3D プリンターによって製作された Try-in デンチャー
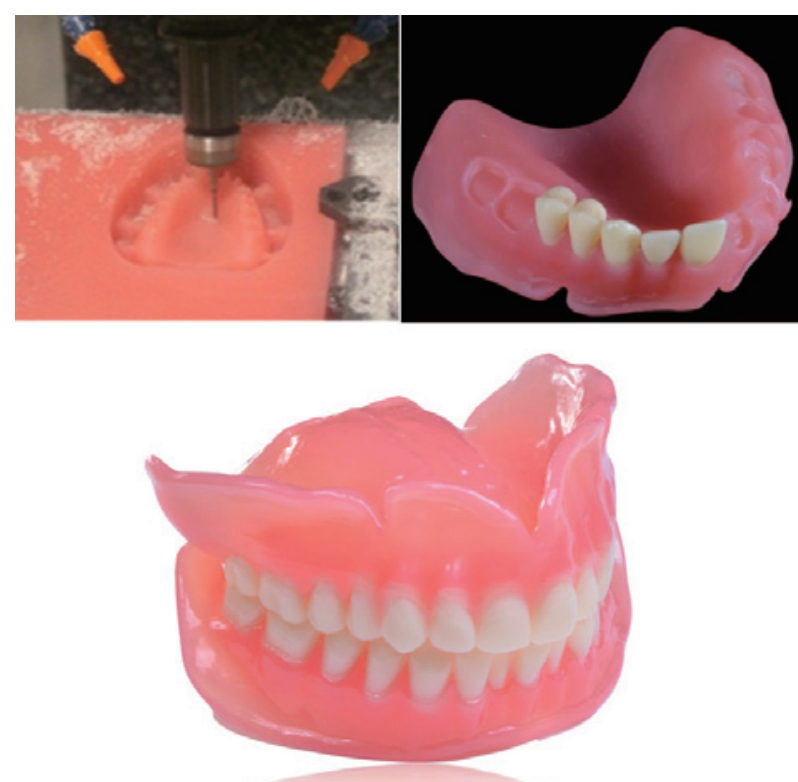

図 4 ミリングによる義歯床の製作と既成人工歯の接着によ り完成した CAD/CAM デンチャー

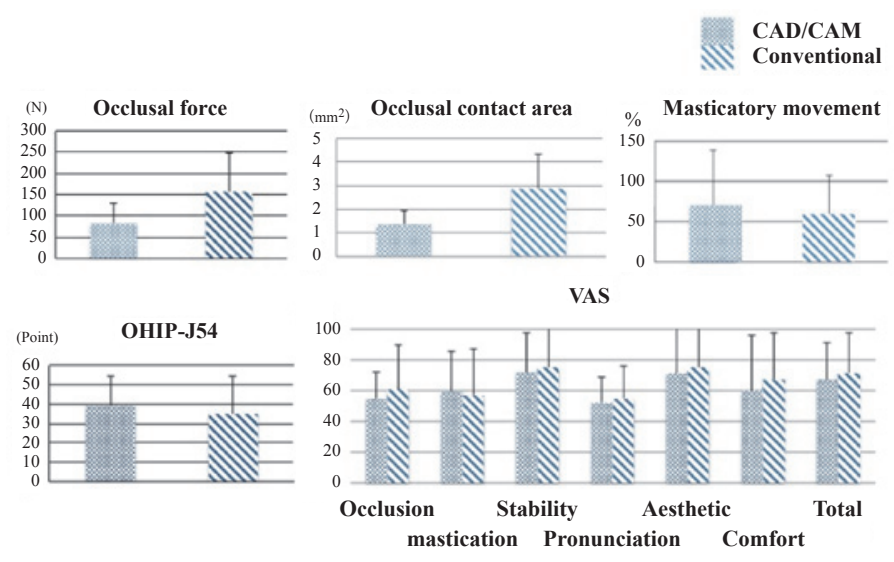

図 $5 \mathrm{CAD} / \mathrm{CAM}$ 法と従来法の臨床評価

もある。しかしながら，CAD/CAM デンチャーの臨 床評価に関する報告は少ない。そこで $\mathrm{CAD} / \mathrm{CAM}$ デ ンチャーの有用性を検証する目的でクロスオーバース タディによる臨床評価を行った。鶴見大学歯学部附属 病院に全部床義歯の新製を希望して来院した上下無歯 顎の 5 名に対し，CAD/CAM デンチャー（DENTCA システム）と従来法を用いた全部床義歯を製作し，各 義歯を 3 週間ずつ使用した後に評価を行った。計測 項目は客観的評価として咀嚼運動，咬合力，咬合接触 面積の計測，主観的評価としてVAS，OHIP-J54 に よるアンケート調査を行った。その結果，客観的評 価では従来法を用いた全部床義歯は CAD/CAM デン チャーと比較して咬合力および咬合接触面積において 有意に良好な值を示した（図 5)。一方，主観的評価
ではVAS，OHIP-J54 ともに有意差は認められなかっ た（図 5)。本研究よりDENTCA システムは調整量 が多いものの, 患者満足度は従来法と大きく変わらな いことが明らかになった ${ }^{3)}$.

\section{CAD/CAM デンチャーのデジタルリリーフ}

現在, 顎骨の CT データと義歯形態は複数のリファ レンスポイントを設定することによって CAD 上で統 合することが可能であり，インプラント領域では既に ガイデッドサージェリーに応用されている ${ }^{4)}$. 有床義 歯治療においても解剖学的情報を精確に抽出し，義歯 に反映することにより，最適な形態が得られると考え られる。そこでオトガイ孔のデジタルリリーフを行っ 


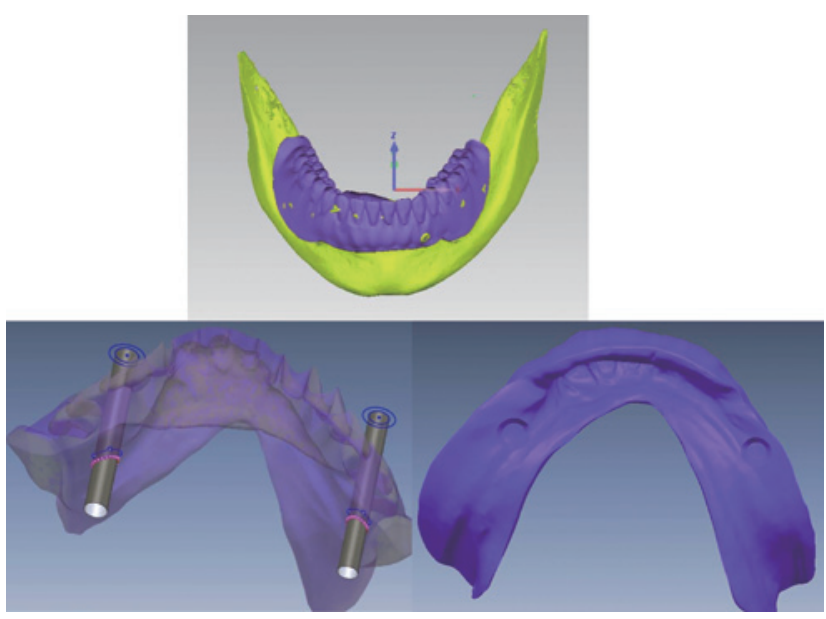

図 6 顎骨と義歯データの統合とオトガイ孔部のデジタルリ リーフ

た症例を報告する。

患者は 80 歳の女性．食事中の痺れを主訴に鶴見大 学歯学部附属病院を受診した。食事開始から $5 \sim 10$ 分経過すると両側の㚘部および口唇部に痺れを訴えて おり，口腔内所見およびX線診査から，高度顎堤吸 収によるオトガイ孔の加圧が原因と診断した。そこ で CT データから正確なオトガイ孔の位置を抽出し, $\mathrm{CAD}$ 上でリリーフを行い CAD/CAM デンチャーを製 作する治療計画を立案した。DENTCA トレーを用い て精密印象採得, ゴシックアーチ描記, 咬合採得を行っ た。印象体をスキャン後，CAD にてデザインされた 義歯デー夕を基に 3D プリンターにより Try-in デン チャーを製作した。試適後，Try-in デンチャーの唇 㚘舌側筋圧面にガッタパーチャにて 8 か所のリファ レンスポイントを設定し，CT の撮影を行った。 CAD 上でCTから得られた顎骨の形状とリファレンスポイ ントの抽出を行った後, 下顎骨と義歯のデザインを 正確に統合し，オトガイ孔の開口部直上を円筒状に リリーフする設計とした（図 6)。最終的にデザイン された義歯形態を CAM にて切削加工し，デジタルリ リーフされた全部床義歯を完成した。装着直後から， 咬合による痺れはまったく認められず，適合も良好で あった（図 7)。また，アンケート調査からも多くの 食品が摂取可能となり, 患者の高い満足が得られた ${ }^{5}$.

\section{IV. デンチャースペース（ピエゾグラフィー）を 考慮した義歯形態の設計}

下顎の高度顎堤吸収や顎骨欠損症例は辺縁封鎖によ る吸着が得られにくく，義歯が脱離しやすい， 口腔諸

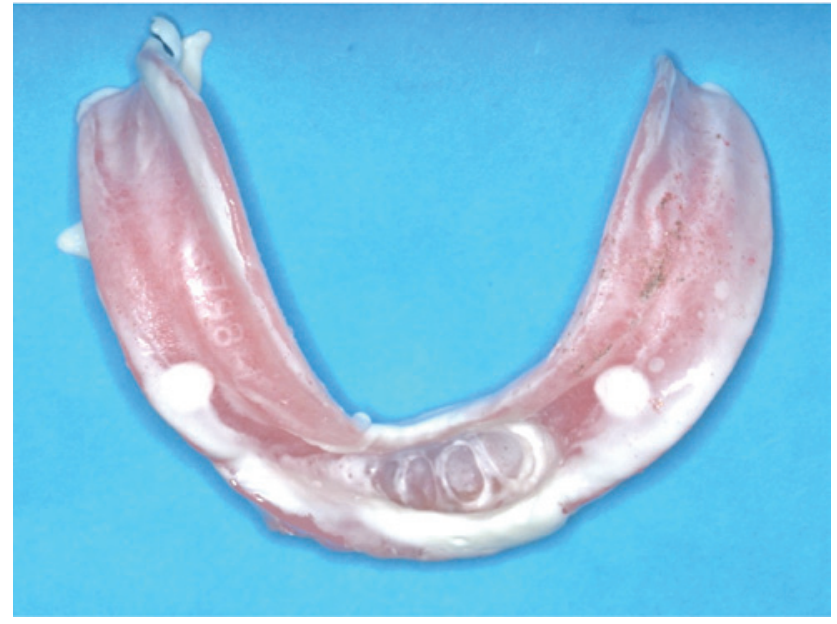

図 7 ミリングによって完成した全部床義歯の適合状態

組織の運動を阻害せずに舌圧や煩圧にて義歯の維持, 安定を獲得するためにはデンチャースペースの採得が 有効である，当講座では下顎全部床義歯に対する生理 的形態の付与を重視しており，デンチャースペース採 得法のなかでもピエゾグラフィーを積極的に臨床応用 している。 ピエゾグラフィーは 1970 年代に Klein ら によって考案された，発音を利用してデンチャース ペースを採得する方法である ${ }^{6)}$. 再現性が高いことや 操作性が良い材料を使用することなどから，有用性も 高いと考えている．ピエゾグラフィーの臨床術式を以 下に示す。(1)通法に従いシリコーン印象材による精密 印象採得と咬合床による咬合採得を行う。 (2)下顎作業 模型上でピエゾグラフィックトレーを製作後，シリ コーン印象材もしくは軟質リライン材を用いて “SIS, SE, SO, TE, DE, MOO, SEEDS” などの発音によりデ ンチャースペースの採得を行う。当講座では流動性の 異なるシリコーン印象材を用い，3〜 4 回に分けて採 得することを推奨している。最初はシリコーン印象材 のへビイボディータイプを用いて小臼歯部から大臼歯 部を記録する。次にミディアムボディタイプを用いて 犬歯まで形成する。最後にフローの良いシリコーン印 象材により前歯部を含めて全体をウォッシュする。 (3) 得られたピエゾグラフィックスペースに従って, 人工 歯排列および義歯床研磨面の形態を蝉義歯に再現し, 口腔内にて試適する。(4)審美性や蝉義歯が転覆しない ことを確認後, 全部床義歯を完成する（図 8). 口唇, 舌および煩粘膜を中心とした口腔諸組織の動的な印象 を行うことにより，生理的な義歯形態を付与すること が可能となる。 また, 完成義歯や使用中の義歯を用い てピエゾグラフィーを採得することにより, 人工歯排 


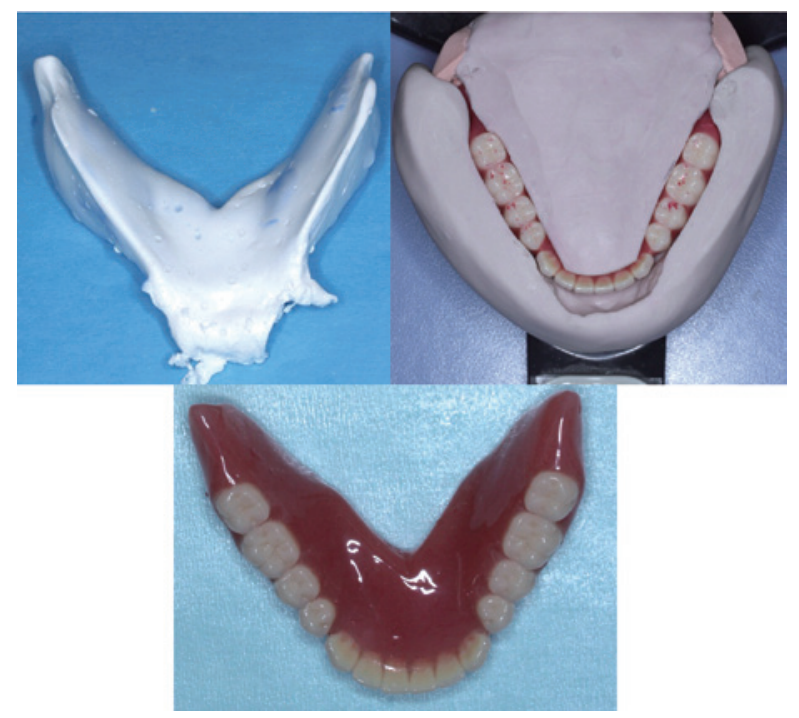

図 8 ピエゾグラフィーに従って製作された全部床義歯

列位置や義歯形態の確認を行うこともできる。通常, CAD/CAM デンチャーにおいて，CAD に入力される 情報は顎堤粘膜面，顎間関係，顔貌形態であり，人工 歯排列位置や義歯床形態は解剖学的ランドマークもし くはプログラミングデータを基に決定され，口腔内の 動態はまったく考慮されていない。そこで，下顎の高 度顎堤吸収に対して，デンチャースペース（ピエゾ グラフィックスペース）の情報を義歯形態に反映し， CAD/CAM デンチャーを装着した症例を報告する.

患者は 82 歳の女性。義歯が外れやすいことを主 訴に鶴見大学歯学部附属病院を受診した。患者は 義歯の安定と快適性を求めていたことから，ピエゾ グラフィーによるデンチャースペース情報を CAD/ CAM デンチャーに組み込む治療計画を立案した。 DENTCAトレーを用いて精密印象採得, ゴシックアー チ描記，咬合採得を行った。得られた顎堤データから 3D プリンターにより床縁の長さを約 $2 \mathrm{~mm}$ 短くした ピエゾグラフィックトレーを製作し，患者の口腔内に てピエゾグラフィーを採得した。得られたピエゾグラ フィックスペースをスキャニング後， CAD 上でシス テムに従ってデザインされたオリジナルの義歯データ と統合することにより，人工歯排列位置および義歯研 磨面形態の修正を行った（図 9)。その結果，オリジ ナルデザインと比較して，人工歯の排列位置は前歯 部で $2 \sim 4 \mathrm{~mm}$ 舌側に，臼歯部で $1 \sim 4 \mathrm{~mm}$ 煩側に 修正された（図 10)。完成した義歯は開口時の脱離等 はなく，維持，安定の向上が認められた。また，VAS によるアンケート調査からも患者の高い満足が得られ た

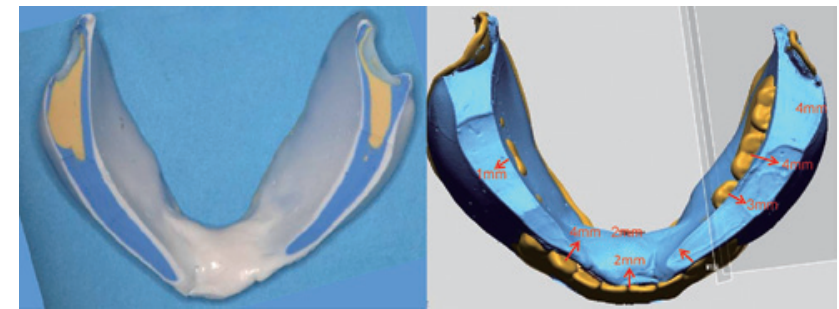

図 9 ピエゾグラフィーとオリジナル義歯デザインデータの統 合

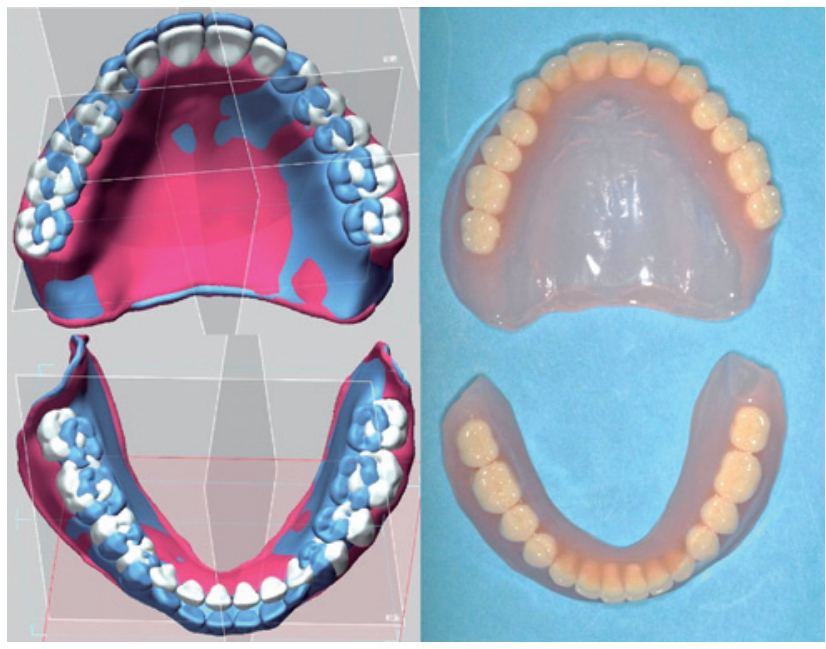

図 10 デンチャースペースを反映させたデザインデータと完 成した全部床義歯（文献 7 より改変引用）

\section{V. 考 察}

DENTCA システムは来院回数を減少できる印象採 得，咬合採得術式であり，義歯床のミリング加工によ る高い強度と適合精度を兼ね備えた CAD/CAM デン チャー製作法のひとつである。加えて，デュプリケー トデンチャーの製作が容易，スタートアップコストや 技工装置が不要であるなどの利点も有している。一方 で，顔貌情報が少ない，トレーの保持が困難でたわ みやすいなどの欠点も挙げられ，今後の改善が期待 される. DENTCA システムの CAD ソフトウェアは CT から得られる DICOM の顎骨情報やデンチャース ペース情報を義歯デザインと正確に統合することが可 能であった。将来的には, 高い精度や強度, 機能性を 有する $\mathrm{CAD} / \mathrm{CAM}$ デンチャーを提供するために，顎 堤粘膜だけでなく，顎骨，顔貌，顎運動，軟組織の動 態などを的確に義歯に反映していくことが重要と考え られる。今回，デンチャースペースの採得に使用した ピエゾグラフィーはシリコーン印象材の使用により, 
印象体の変形が少なく，スキャンしやすいことから， CAD/CAM デンチャーに反映する方法として適して いると考えられる。しかしながら，依然としてアナロ グの記録方法であり，デンチャースペースのデジタル 採得法は存在していない. DENTCA システムに限ら ず, 現在, 臨床応用されている $\mathrm{CAD} / \mathrm{CAM}$ デンチャー はいずれのシステムもフルデジタル化には至っておら ず，特に口腔内スキャナーは辺縁形成や加圧印象がで きない, 口蓋部の印象に時間を要する, 舌運動の処理, デー夕容量が大きい, 費用が高額など未解決な問題が 残されている。現状では専用のトレーやデュプリケー トデンチャーを使用して辺縁形成, 加圧印象を行わざ るを得ないが，フルデジタル化に向けて静的，動的な デジタルインプレッションの開発が期待される.

高齢者人口は年々増加し, 可撤性義歯のニーズはま すます高くなっている．治療回数の減少や口腔内での 煩雑な操作を必要としないフルデジタルプロセスによ る $\mathrm{CAD} / \mathrm{CAM}$ デンチャーが実現すれば，患者だけで なく，歯科医師や歯科技工士にも多大な恩恵を与える ことになる。

\section{VI. 結 論}

DENTCA システムを利用することにより来院回数 を減少し, 義歯床の高い適合性と強度を有する全部床 義歯を装着できたことから，CAD/CAM デンチャー 製作法のひとつとして臨床応用可能であることが示唆 された。また, CAD 上でCTからの解剖学的情報や デンチャースペース情報を義歯のデザインに統合する ことが可能であり, 幅広い症例に適用できると考えら
れた。しかしながら, 通法と比較して多くの調整を要 することもあり, システムや術式, トレーの細部にさ らなる改善が必要であると考えられた。

\section{文献}

1) Kim T, Duarte S. CAD/CAM technology for complete denture fabrication. Quintessence Dent Technol 2015; 178-188.

2) Kim T, Michel M. 3D printed complete dentures. Quintessence Dent Technol 2016; 141-149.

3) Kurihara D, Tokue A, Matsui T, Sato M, Nakata T, Kohi $\mathrm{K}$ et al. Clinical assessment of the DENTCA system for complete denture construction in two visits. Indonesian Prosthodontic Society and Japan Prosthodontic Society joint meeting Proceeding. 2014; 63.

4) D'haese J, Ackhurst J, Wismeijer D, De Bruyn H, Tahmaseb A. Current state of the art of computerguided implant surgery. Periodontol 2000 2017; 73: 121-133.

5) Ohkubo C, Park EJ, Kim TH, Kurtz KS. Digital relief of the mental foramen for a CAD/CAM fabricated mandibular denture. J Prosthodont 2016. [Epub ahead of print]

6) Klein P. Piezography: dynamic modeling or prosthetic volume. Actual Odontostomatol 1974; 28: 266-276.

7) Ohkubo C, Shimpo H, Tokue A, Park E, Kim T. Complete denture construction using piezography and CAD/CAM. J Prosthet Dent 2017. in press

著者連絡先: 新保 秀仁

干 230-8501 横浜市鶴見区鶴見 2-1-3

鶴見大学有床義歯補綴学講座

Tel: 045-580-8420

Fax: 045-573-9599

E-mail: shinpo-hidemasa@tsurumi-u.ac.jp 